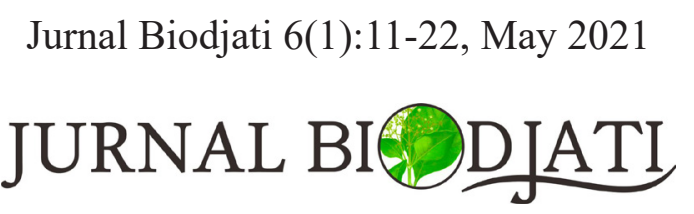

e-ISSN : 2541-4208

p-ISSN : 2548-1606

http://journal.uinsgd.ac.id/index.php/biodjati

\title{
HYDROPRIMING IMPROVES GERMINATION AND PLANT RECOVERY DURING EMBRYO RESCUE OF WILD BANANA Musa acuminata var. tomentosa
}

\author{
Apriliana Dyah Prawestri ${ }^{1 *}$, Indira Riastiwi ${ }^{2}$, Resa Sri Rahayu ${ }^{3}$, Tri Handayani ${ }^{4}$ \\ Aryani Leksonowati ${ }^{5}$ Yuyu Suryasari Poerba ${ }^{6}$
}

\begin{abstract}
Selected paper from the $5^{\text {th }}$ Seminar Nasional Biologi (SEMABIO), Bandung-Indonesia, October 8, 2020 (conference.bio.uinsgd.ac.id)

Received : December 10, 2020

Accepted : April 24, 2021
\end{abstract}

DOI: 10.15575/biodjati.v6i1.10528

1,2,3,4,5,6 Research Center for Biology, Indonesian Institute of Sciences (LIPI), J1. Raya Jakarta-Bogor km. 46, Cibinong, Bogor, West Java 16911 phone: (+62)21-8765058, fax: $(+62) 21-87907612$

e-mail:

*1ad.prawestri@gmail.com

indirariastiwi@gmail.com

3resa.rahayu@gmail.com

trihandayani08@gmail.com

5aryanileksonowati@gmail.com

6yuyupoerba@gmail.com

*Corresponding author

\begin{abstract}
Wild bananas are believed to have genes for resistance to biotic and abiotic stress in nature, making them potential genetic resources for creating superior varieties. Wild banana seeds, such as Musa acuminata var. tomentosa are generally difficult to germinate in vivo, so that in vitro embryo culture technique is needed. This study aimed to increase embryo germination and regeneration of wild banana M. acuminata var. tomentosa by soaking the seeds as hydropriming. The treatment comprised of soaking the seeds in sterile distilled water for four periods of time: 0 (control), 1, 4, and 7 days. A total of 45 embryos for each treatment were planted on petri dishes containing $M S+0.5 \mathrm{mg} / \mathrm{L} \mathrm{BA}+1 \mathrm{mg} / \mathrm{L}$ biotin $+1 \mathrm{mg} / \mathrm{L}$ proline. The results showed that hydropriming increased the rate of embryo germination and regeneration. Seeds soaked for 1, 4, and 7 days successfully resulted in embryo germination percentages of $87 \%, 62 \%$, and $62 \%$, respectively, while the control unsoaked seeds germinated with a lower percentage of $42 \%$. One-day soaking treatment was the most optimal treatment to increase the rate of germination and regeneration as well as obtained the best vigor as demonstrated by the highest average height of plantlets, number of leaves, and roots than other treatments. Thus, 1-day seed hydropriming is the best treatment for embryo rescue and regeneration of wild banana M. acuminata var. tomentosa.
\end{abstract}

Keywords: embryo rescue, germination, regeneration, seeds soaking, wild banana

\section{Citation}

Prawestri, A. D., Riastiwi, I., Rahayu, R. S., Handyani, T., Leksonowati, A. \& Poerba, Y. S. (2021). Hydropriming Improves Germination and Plant Recovery During Embryo Rescue of Wild Banana Musa acuminta var. tomentosa. Jurnal Biodjati, 6(1), 11-22.

\section{INTRODUCTION}

The wild bananas, Musa acuminata Colla of Musaceae family in various regions of Indonesia were diverse and differentiated into 15 varieties (Nasution \& Yamada, 2001), one of which var. tomentosa is endemic to
Sulawesi (Nasution \& Yamada, 2001; Sulistyaningsih, 2013; Christelová et al., 2017; Poerba et al., 2018). Wild bananas have been known to have resistance to abiotic stress such as drought stress (Santos et al., 2018) and biotic stress such as Fusarium wilt disease (Zhang et al., 2019). Therefore, wild 


\section{Jurnal Biodjati 6(1):11-22, May 2021 \\ JURNAL BI@DIATI}

http://journal.uinsgd.ac.id/index.php/biodjati

bananas as genetic sources are important for the banana's future genetic improvement, especially as disease-resistant diploid parental lines (Tenkouano et al., 2003; Wu et al., 2016).

Banana seeds are naturally survived with low water content but have a different dormancy type and experience secondary dormancy as the seeds stored (Kallow et al., 2020). Usually, after months of storage seed viability became reduced and low seedling vigor (Bohra et al., 2020). Some wild bananas have seeds with little endosperm, and some have abnormalities because of the absence and/or deformation of the embryo (Silva et al., 2019). In order the seed to germinate, the embryo has to contact water to be non-dormant. Besides, dry ripe banana seeds have a hard texture with an impermeable inner surface of the seed coat; thus, they mostly fail to germinate due to lack of water supply or exchange of gases (Arun et al., 2013). Rescuing the embryo seems to be the best way to overcome this obstacle, which has significantly enhanced germination compared to conventional sowing the seeds (Wilson \& Tenkouano, 2019).

Embryo culture has been studied to increase germination of various plant species, including wild Musa (Bakry, 2008). The study included factors that affect plant regeneration such as seed age (Uma et al., 2012), seed storage and priming time (Wilson \& Tenkouano, 2019), types of seed, concentration of plant growth regulators, and other components of in vitro media (Asif et al., 2001; Dayarani et al., 2014).

Treatment of seeds priming by soaking seeds in water (hydropriming) and other chemical compounds (osmopriming) for a particular time potentially increases the ability of wild banana seeds to germinate. Seeds priming has been tested in several plants, such as lychees (Zhang et al., 2015), culantro
Eryngium foetidum (Mozumder \& Hossain, 2013), tomatoes (Sabongari \& Aliero, 2004), and pistachios (Esmaeilpour \& Van Damme, 2016). The success of seed priming in increasing germination is influenced by several factors such as the type of priming, concentration of the chemical compound, imbibition time, and the variety of species (Pawar \& Laware, 2018).

Hydropriming of Musa seeds has been done by Arun et al. (2013), however, the success rate of seed germination is low, below $50 \%$, after hydropriming treatment for 1 to 5 days. In addition, beyond three days, germination decreased with a delay in germination which might be caused by microbial contamination. Diro \& Van Staden (2003) also reported that the pretreatment of soaking Ensete ventricosum seeds for four days resulted in $95 \%$ microbial contamination of Oniya genotype embryo culture. No other reports regarding the seed hydropriming treatment, especially the soaking time of wild Musa seeds hydropriming on embryo germination, microbial contamination and seedling growth, have been found. Therefore, this study was undertaken to determine the effect of seeds hydropriming and soaking time on in vitro embryo germination and plantlet growth and recovery of wild banana M. acuminata var. tomentosa.

\section{MATERIALS AND METHODS}

This study was conducted from June to October 2020. The seeds of M. acuminata var. tomentosa used was the collection of Plant Genetics Laboratory, Research Center for Biology - LIPI, Cibinong, West Java. The seeds were extracted from fruit bunches harvested from $M$. acuminata var. tomentosa plants in the living collection field of the Research Center for Biology. The seeds were stored at room temperature for one month before using them as experiment materials. 


\section{JURNAL BIDDJATI}

http://journal.uinsgd.ac.id/index.php/biodjati

\section{Hydropriming Treatment}

Seeds hydropriming treatments were carried out referring to Arun et al. (2013) with a modification in soaking time, i.e. 0 (without soaking), 1, 4, and 7 Days at room temperature. A total of 360 banana seeds were divided into four, 90 seeds for each soaking period. Those seeds soaked separately in $25 \%$ commercial bleach $(5.25 \% \mathrm{NaOCl})$ for 15 min, rinsed with sterile distilled water once, soaked again in $80 \%$ alcohol for $10 \mathrm{~min}$. Without rinsing, the seeds were then drained on several layers of autoclaved sterile tissue in a petri dish. The disinfected seeds were then soaked in $50 \mathrm{~mL}$ vials containing $40 \mathrm{~mL}$ sterile distilled water, then stored for 1,4 , and 7 Days separately at room temperature for hydropriming treatment. Each treatment vial contained 90 disinfected seeds. The soaking water that became turbid during the treatment period indicated contamination so that the seeds were re-sterilized with $80 \%$ alcohol for 15 mins before culture. Seeds were carefully split using a sterile blade to take out the embryo. Banana embryos were characterized by a small yellowish-white dense sphere located at the end of the micropyle, while endosperm was a white powder filling the seed (Figure 1).

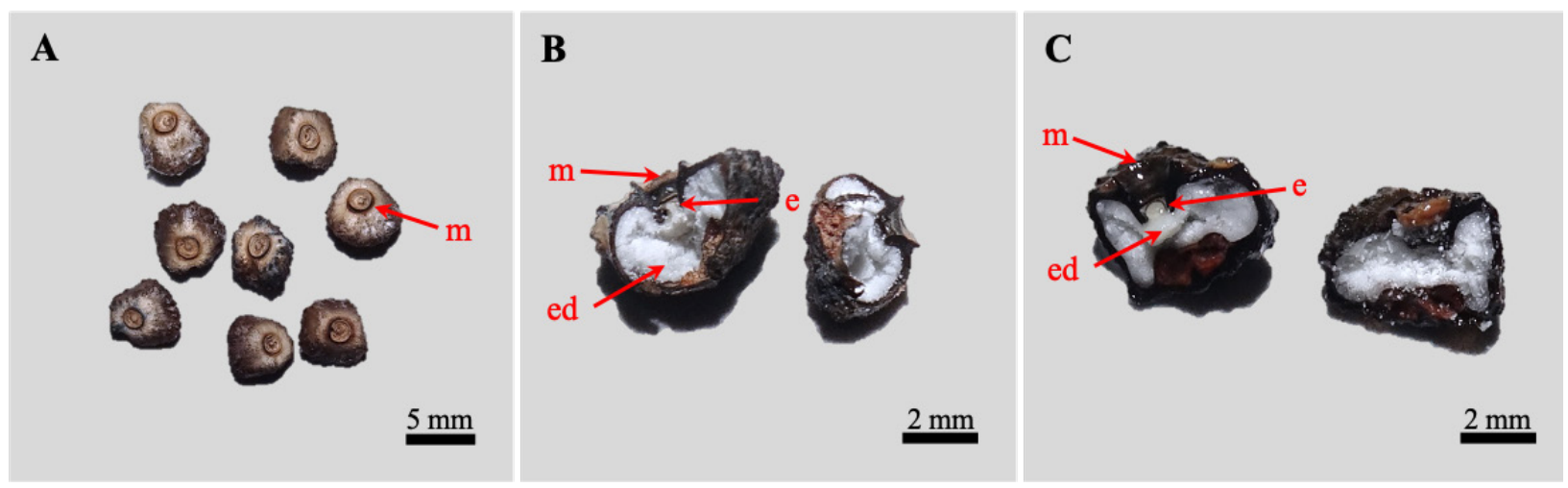

Figure 1. Seed morphology of M. acuminata var. tomentosa. A) Dried mature seeds; B) Opened seed without soaking treatment (control), the embryo is ivory white located at the inner end of micropyle; C) Opened seed after soaking for one day, the embryo is swollen and its color tends to be yellowish. Arrows indicate: e= embryo, $\mathrm{ed}=$ endosperm, $\mathrm{m}=$ micropyle.

\section{Embryo Culture Initiation on Germination Media}

A total of 90 disinfected unsoaked seeds used as a control were taken as many as 45 seeds randomly and immediately excised to extract the embryos and planting them on three petri dishes containing germination media. As hydropriming treatment, after each soaking period, 45 seeds were taken randomly from each soaking vial. A total of 45 embryos from each treatment were extracted from seeds using a sterile blade and planted on three petri dishes containing germination media.
The germination medium was solid modified MS (Murashige \& Skoog, 1962) containing MS macro and micro salts, MS vitamin, $100 \mathrm{mg} / \mathrm{L}$ myoinositol, $30 \mathrm{~g} / \mathrm{L}$ sugar supplemented with $1 \mathrm{mg} / \mathrm{L}$ biotin, $1 \mathrm{mg} / \mathrm{L}$ proline, and $0.5 \mathrm{mg} / \mathrm{L}$ benzyl-adenine (BA) and $3 \mathrm{~g} / \mathrm{L}$ gelrite as the gelling agent. The $\mathrm{pH}$ of the medium was adjusted to 5.7-5.8 with a few drops of either $1 \mathrm{~N} \mathrm{NaOH}$ or $1 \mathrm{~N} \mathrm{HCl}$ before the gelling agent was added. The medium was autoclaved at $121{ }^{\circ} \mathrm{C}$ for $20 \mathrm{~min}$ and poured in $25 \mathrm{~mL}$ aliquots into the sterilized glass petri dish of $15 \times 10 \mathrm{~mm}$ under 


\section{Jurnal Biodjati 6(1):11-22, May 2021 \\ JURNAL BI@DIATI}

http://journal.uinsgd.ac.id/index.php/biodjati

aseptic condition inside a laminar flow hood.

The cultures were then incubated on a shelf in the culture room without lighting for four weeks at $25^{\circ} \mathrm{C}$. Parameters observed were seed morphology, percentage of germination, and culture contamination. Germination was characterized by the appearance of light green shoots in the embryo culture, while contamination was indicated by the presence of mucus caused by bacterial or yeast or hyphae grown by fungi on the media or embryo. The process of developing embryos into plantlets was observed using a stereomicroscope (Nikon SMZ1000).

\section{Sprout Transplanting on Regeneration Media}

After four weeks in the germination media, the embryos with grown shoots of $1 \mathrm{~cm}$ length were transferred to regeneration media for further development into plantlets. The regeneration medium used was solid MS media, containing MS macro and micro salts, MS vitamin, $100 \mathrm{mg} / \mathrm{L}$ myoinositol, $30 \mathrm{~g} / \mathrm{L}$ sugar supplemented with $1 \mathrm{mg} / \mathrm{L}$ biotin, $2 \mathrm{mg} / \mathrm{L}$ BA, solidified with $3 \mathrm{~g} / \mathrm{L}$ gelrite, and autoclaved at $121^{\circ} \mathrm{C}$ for $20 \mathrm{~min}$. The culture vessel were glass bottles with a volume of 350 $\mathrm{mL}$ containing $30 \mathrm{~mL}$ medium capped with double-layer plastic film and secured with rubber bands. There were 3 shoots developing embryos per culture vessel.

Cultures were incubated for four weeks with a $16 / 8 \mathrm{~h}$ photoperiod in a culture room with 2000-3000 lux light intensity (46 $\mu \mathrm{mol} /$ $\left.\mathrm{m}^{2}\right)$, at $25 \pm 2{ }^{\circ} \mathrm{C}$ room temperature, and $40 \%$ humidity. Growth parameters were observed four weeks after sub-culturing, including shoot height, number of leaves, number of roots, root length, and the color of 15 plantlets randomly selected from each soaking treatment.

\section{Statistical Analysis}

Plantlet growth data were analyzed using the Kruskal-Wallis test at a 95\% confidence interval. Significant differences $(\mathrm{P} \leq 0.05)$ between individual treatment means were determined using Duncan's Multiple Range Test (DMRT). All the data were analyzed using Statistical Analysis System 9.1 (SAS 9.1) software (Mattjik \& Sumertajaya, 2013).

\section{RESULTS AND DISCUSSION}

We have been able to improve the germination and plantlet regeneration by embryo rescue of wild Musa acuminata var. tomentosa by hydropriming month-old-stored seeds in sterile water for 1 day prior to culture. With that best seed hydropriming treatment, embryo germination percentage doubled to over $80 \%$ and the subsequently regenerated plantlets were most vigorous.

\section{Effect of Seeds Hydropriming on Embryo Germination}

Dry mature ripe banana seeds of M. acuminata var. tomentosa are hard, coarse in texture, dark brown. Seeds of this species are filled with endosperm in the form of starch grains. This kind of seed was typical of wild banana $M$. acuminata seeds, such as subsp. banksii (Kallow et al., 2020), subsp. burmannica (Uma et al., 2012) and var. sumatrana (Roostika et al., 2019). The embryo located at the end of the inner micropyle was ivory white, slightly different from the surrounding milky-white endosperm. The embryo was mushroom-shaped with a welldeveloped haustorium and meristematic stalk. The soaking of the seeds affects the size and color of the embryo; the embryos from soaked seeds were larger than those of unsoaked seeds. The imbibition process during immersion might have caused the swelling of 


\section{JURNAL BIDDJATI}

http://journal.uinsgd.ac.id/index.php/biodjati

the embryos. The embryos from soaked seeds had a more slight yellow tint color than those from unsoaked seeds (Figure 1).

The embryo development stage of M. acuminata var. tomentosa on germination medium could be categorized into 3 stages: (i) pre-germination stage, characterized by embryo swelling (Figure 2A); (ii) germination stage, starting with the enlarge embryo differentiated haustorium-embryo zone, with coleoptile and rhizoid started to emerge. The coleoptile was light green and continue to elongate but not break open yet, and the rhizoid was indicated by hairy radicle development (Figure 2B-C); (iii) coleoptile elongation (Figure 2D); (iv) regeneration stage, characterized by the growth of secondary roots at basal part and coleoptile continue to enlarge at the apical and about to break by the emergence of the first leaf (Figure 2E).
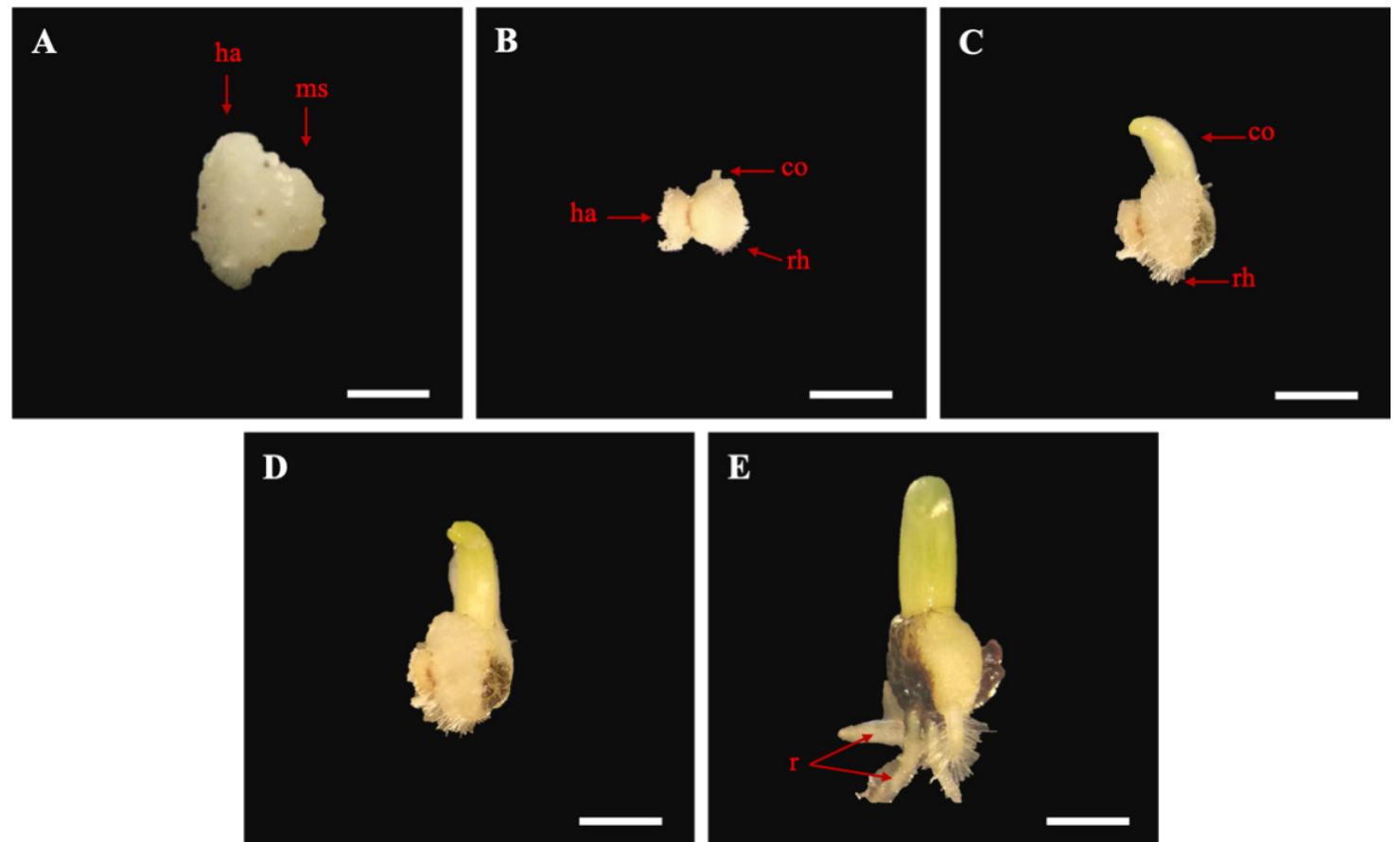

Figure 2. The stages of embryo development of M. acuminata var. tomentosa on germination medium. A) An embryo swelled after one day of culture. The embryo was mushroom-shaped with a welldeveloped haustorium and meristematic stalk; B) The embryo grew bigger, differentiated haustorium-meristematic zone, with coleoptile and rhizoid in the meristematic stalk started to emerge (10 days old); C) The emergence of light green coleoptile with hairy radicle development (14 days old); D) Coleoptile elongation (16 days old); E) Root growth (22 days old) at basal part and coleoptile continued to enlarge at the apical. Arrows indicate: $c o=$ coleoptile, ha= haustorium, $\mathrm{ms}=$ meristematic stalk, $\mathrm{r}=$ root, $\mathrm{rh}=$ rhizoid. Bar: $\mathrm{A}=500 \mu \mathrm{m}, \mathrm{B}-\mathrm{E}=2 \mathrm{~mm}$.

Banana embryos of M. acuminata var. tomentosa that were planted on germination medium began to germinate at 2 weeks of culture (WOC). Hydropriming affected the percentage of embryo germination. The embryos of unsoaked seeds (control) germinated only at $16 \%$ in the second week and increased only Jurnal Biodjati 6(1):11-22, May 2021 up to $40 \%$ a maximum of $42 \%$ in the third and fourth week, respectively. Of all the seed hydropriming treatments, 1-day soaking increased the germination percentage to a relatively high percentage of $40 \%$ at $2 \mathrm{WOC}$, then continued to increase to $84 \%$ at $3 \mathrm{WOC}$ and plateau at $87 \%$ at 4 WOC. However, in the 


\section{Jurnal Biodjati 6(1):11-22, May 2021 \\ JURNAL BIDDJATI}

http://journal.uinsgd.ac.id/index.php/biodjati

4-day hydropriming treatment, the embryo germination occurred faster than other treatments due to a much higher percentage which was $62 \%$ at 2 WOC, although this percentage value did not increase again at the third and fourth weeks due to an increase in the rate of contamination (Figure 3). The longer seed hydropriming duration of 7 days, resulted in a germination rate of $34 \%$ at 2 WOC which was slightly less than that of 1-day hydropriming treatment but then its germination rate plateau at $64 \%$ at 3 to 4 WOC similar to that of 4-day hydropriming treatment. These results indi- cated that 1-day soaking treatment was the most optimal treatment to enhance the rate of germination. These are similar to the results of Esmaeilpour \& Van Damme (2016) that reported a 1-day (24 h) hydropriming pre-treatment increased the percentage of germination in pistachio seeds compared to 1,6 , and 12 $\mathrm{h}$ duration. This could be due to hydropriming treatment that triggered reactivation of the metabolic system, leading to the rehydration of proteins, enzymes, and cellular organelles in the seed Arun et al. (2013).

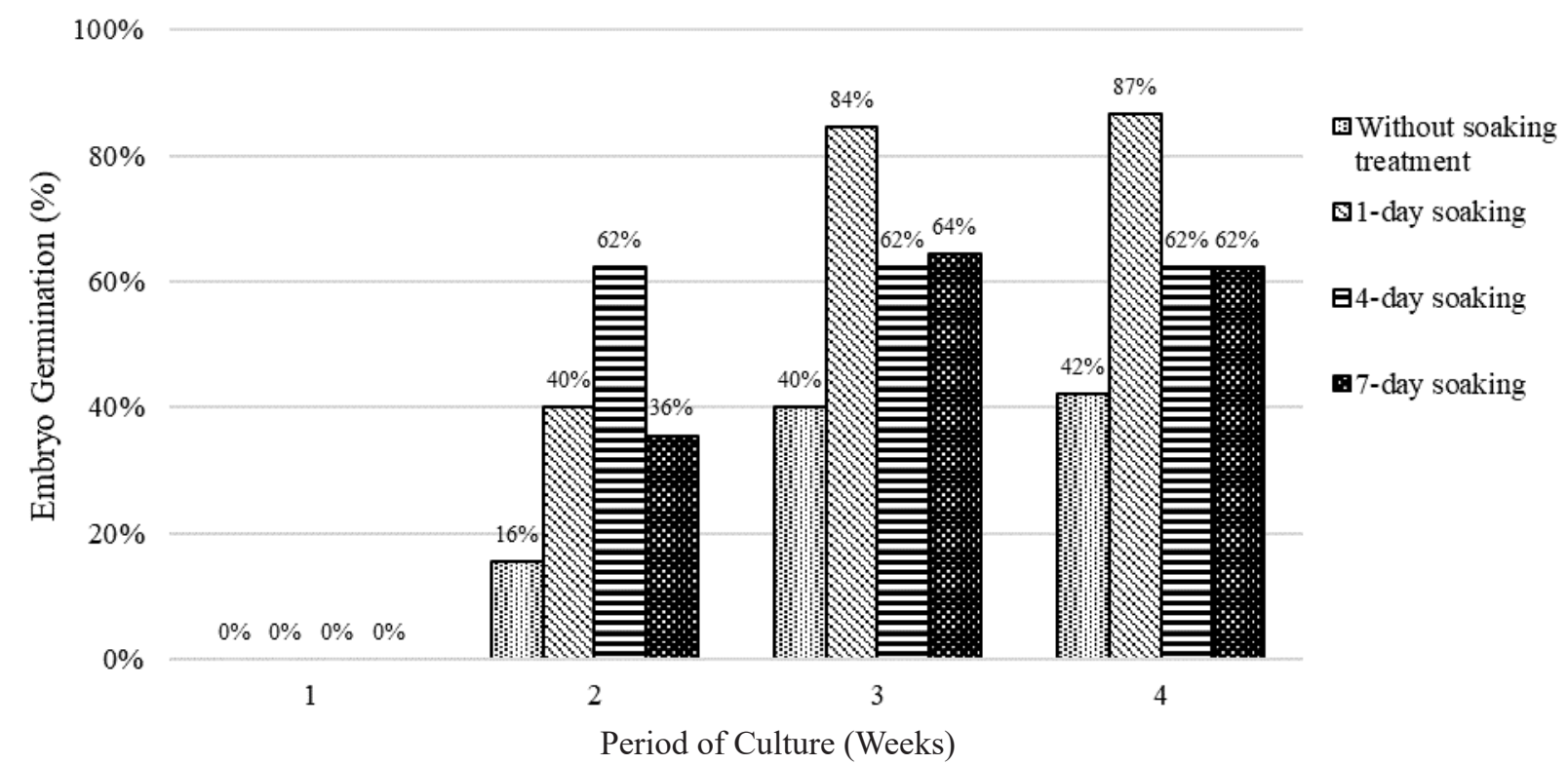

Figure 3. Effect of seed soaking duration on germination percentage of the embryo for four weeks of culture on germination media.

In the present study, the decrease in the percentage of embryo germination in the 4 and 7-day hydropriming is in line with the findings of Arun et al. (2013) who have reported that beyond three days of hydropriming period, the embryo germination percentage of Pisang Jajee $\times M$. acuminata ssp. burmannicoides decreased. It might be caused by bacterial decay of the embryo prior to germination, and inadequate duration with too long soaking period resulting in inactivation Prawestri et al. of the enzyme that facilitating the germination (Esmaeilpour \& Van Damme, 2016). On the other hand, this result is in contrast to a previous study in Eryngium foetidum that the percentage of germination increased along with the length of the soaking period (Mozumder \& Hossain, 2013).

Hydropriming of $M$. acuminata var. tomentosa wild bananas seeds was effective in improving the embryo germination from 40 to $80 \%$ upon embryo rescue of seeds that 


\section{Jurnal Biodjati 6(1):11-22, May 2021 \\ JURNAL BI@DIATI}

http://journal.uinsgd.ac.id/index.php/biodjati

had been stored about a month and apparently had diminished their germination ability. Fresh wild banana seeds that are mature and characterized with fully developed embryo and powdery endosperm could be used for embryo rescue with plantlet recovery near 90\% for Pisang Jajee (AA) (Uma et al., 2011), up to $100 \%$ for M. acuminata var. sumatrana (Roostika et al., 2019) and subsp. malaccensis (Asif et al., 2001), however, after some period of storage and desiccation the germination rate decreases to variable value from 10 to 80\% (Kallow et al., 2020).

Priming seeds, especially soaking in water (hydropriming), accelerates the process of imbibition and enzyme activation. During immersion, enzymes, such as amylase and lipase, are stimulated and produced to activate certain materials in the seeds and mobilize antioxidant enzymes that delay oxidation processes in the seeds to remain vigorous (Siddique \& Kumar, 2018). In addition, water also causes the embryonic cell wall and seed coat more permeable to gases, thus facilitates the diffusion of oxygen into the cells to increase the respiratory activity of the embryonic cells so that the process of seed germination occurs faster (Taiz \& Zeiger, 1998). According to Tania et al. (2019), seed priming treatment can stimulate a series of biochemical changes in the seeds to initiate important processes such as breaking dormancy and hydrolysis.

Water immersion treatment as priming had both positive and negative effects. Although soaking seeds were able to increase the germination percentage of embryos, it appeared that this treatment also negatively affected the risk of contamination of embryo cultures. The data in Figure 4 shows that the unsoaked seeds control treatment resulted in no embryo culture contamination, while both bacteria and fungi contaminated the embryo culture from the treatment of hydropriming. The level of contamination in the embryo culture was directly proportional to the seed hydropriming, i.e., 7 to $31 \%$ contamination rate with immersion duration from 1 to 7 days.

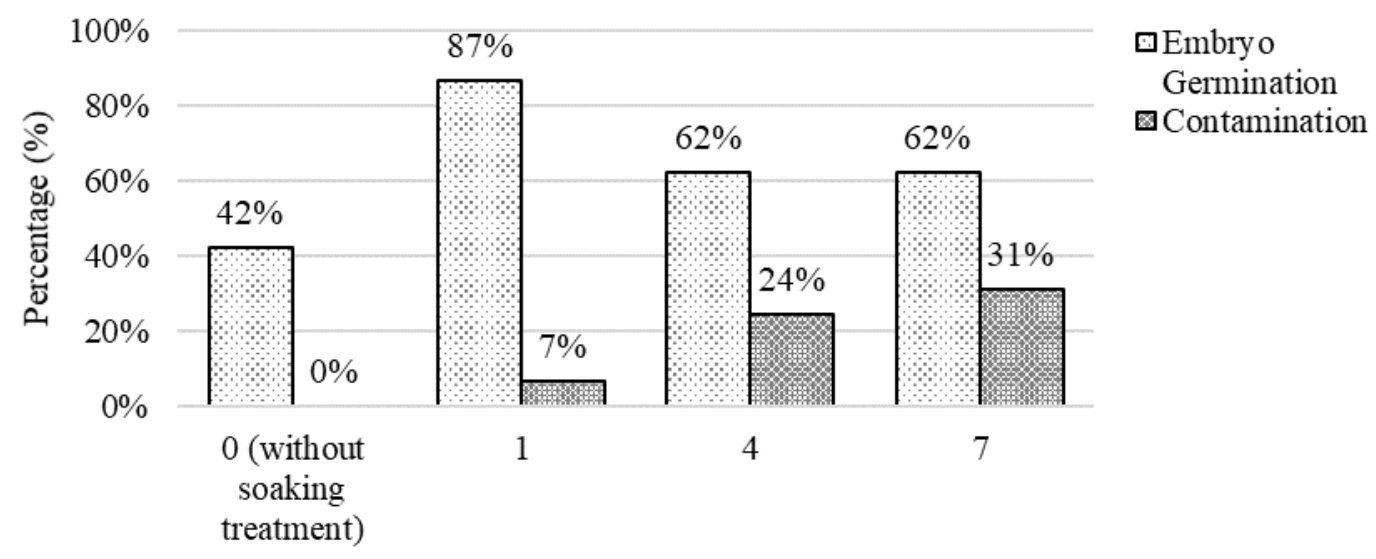

Soaking Duration (days)

Figure 4. Comparison of the percentage of embryo germination and embryo culture contamination, observed at 4 weeks after planting on germination media. 


\section{Jurnal Biodjati 6(1):11-22, May 2021 \\ JURNAL BI@DIATI}

http://journal.uinsgd.ac.id/index.php/biodjati

During the soaking treatment, contamination began to appear indicated by cloudy soaking water. A rescue procedure of re-sterilizing the contaminated banana seeds before culture on the germination media was not completely successful as indicated by contamination of the embryos at 4 weeks of culture. This contamination could be caused by several possibilities, including the more extended soaking (4 and 7 days), which would increase the time for bacteria/fungi to grow in the water used for soaking. The increased water content in the seeds could trigger endophytic microbe growth in the seeds.

According to Frank et al. (2017), endophytic microbes that benefit from supporting growth are consistently transferred across generations through vertical transmission via seeds. Endophytic microbes in seeds are also reported to grow from surface-sterilized seeds of the various seeds crops, including corn, alfalfa, pods, barley, and wild plants like giant Cardon cactus (Pachycereus pringlei) and Norway spruce (Picea abies). Endophytic bacteria are detected in several parts of the seed, including the seed coat, endosperm, and embryogenic tissue.

\section{Plantlet Regeneration from Germinating Embryos}

Upon transfer to the regeneration medium, the germinating embryos of $M$. acuminata var. tomentosa as indicated by the growth of coleoptiles and radicles continued to grow into plantlets as indicated by the emergence of first leaves from coleoptile, then the subsequent leaves, and the growth of roots (Figure 5). Different seed hydropriming treatments that resulted in the different embryo germination rates continued to show different plantlet vigor upon their growth in the regeneration medium. The plantlets were more vigorous when the seeds were hydroprimed compared to control unsoaked seeds, and the best hydropriming treatment that allowed the most vigorous plantlet growth was the 1-day duration (Figure 5). More detailed observation at 4 weeks after culture in the regeneration medium showed that the difference in the vigor of the plantlets was attributed to the significant difference in plantlet height and number of leaves, while the number of the shoots and the number of roots developed from the plantlet were not significantly different (Table 1). It was also noticeable that the plantlets from hydroprimed seed had a darker green color compared to plantlets from control unsoaked seeds.

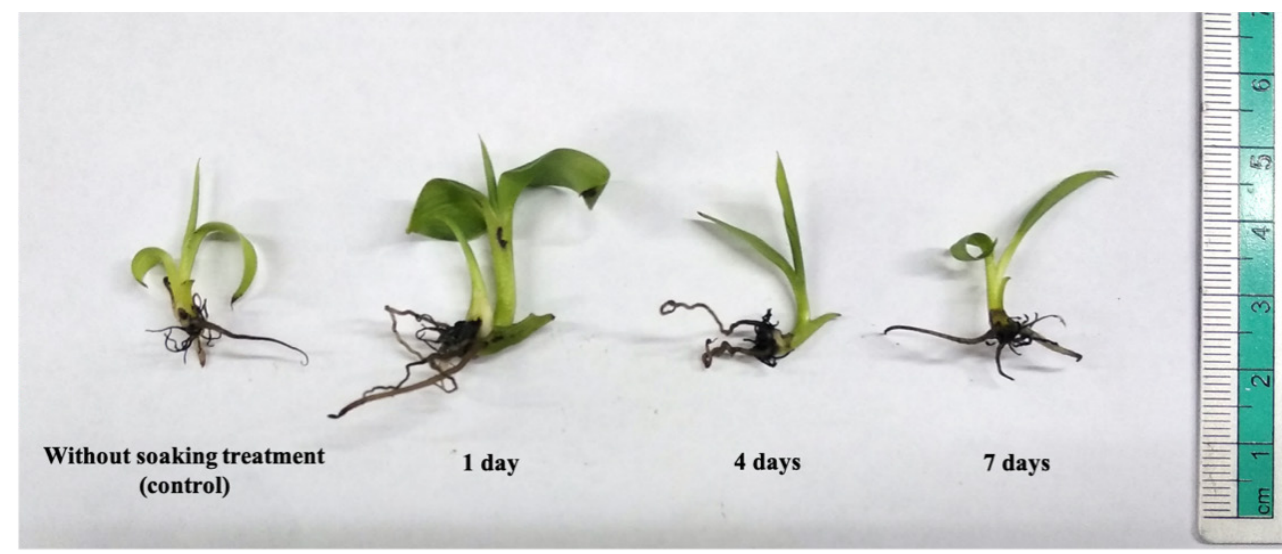

Figure 5. Performance of M. acuminata var. tomentosa plantlets regenerated from embryos of unsoaked and soaked seeds for various days at 4 weeks cultured on regeneration medium. 


\section{Jurnal Biodjati 6(1):11-22, May 2021 \\ JURNAL BIDDJATI}

http://journal.uinsgd.ac.id/index.php/biodjati

Table 1. Effect of seed soaking duration on subsequent plantlet growth at 4 weeks after cultured on regeneration medium.

\begin{tabular}{lccccc}
\hline $\begin{array}{c}\text { Hydropriming } \\
\text { Treatment }\end{array}$ & $\begin{array}{c}\text { Shoot Height } \\
(\mathrm{cm})\end{array}$ & $\begin{array}{c}\text { Number of } \\
\text { Shoots }\end{array}$ & $\begin{array}{c}\text { Number of } \\
\text { Leaves }\end{array}$ & $\begin{array}{c}\text { Number of } \\
\text { Roots }\end{array}$ & $\begin{array}{c}\text { Shoot } \\
\text { Colour }\end{array}$ \\
\hline Without soaking & $1.31 \pm 0.124 \mathrm{~b}$ & $1.00 \pm 0.098 \mathrm{a}$ & $0.93 \pm 0.182 \mathrm{~b}$ & $4.93 \pm 0.831 \mathrm{a}$ & Light green \\
1-day soaking & $2.56 \pm 0.161 \mathrm{a}$ & $1.00 \pm 0.000 \mathrm{a}$ & $1.47 \pm 0.165 \mathrm{a}$ & $6.27 \pm 0.597 \mathrm{a}$ & Dark green \\
4-day soaking & $1.70 \pm 0.215 \mathrm{~b}$ & $0.87 \pm 0.091 \mathrm{a}$ & $1.20 \pm 0.200 \mathrm{ab}$ & $4.73 \pm 0.902 \mathrm{a}$ & Dark green \\
7-day soaking & $2.31 \pm 0.250 \mathrm{a}$ & $0.93 \pm 0.067 \mathrm{a}$ & $1.00 \pm 0.138 \mathrm{ab}$ & $5.27 \pm 0.983 \mathrm{a}$ & Dark green \\
\hline
\end{tabular}

Values are mean \pm standard error. Values followed by different letters within a column are significantly different according to Duncan's Multiple Range Test $(\mathrm{P}<0.05)$.

The in vitro embryo germination of wild banana var. tomentosa followed a typical monocotyledonary species which was started with embryo enlargement due to imbibition, rhizoid, and coleoptile development and plant growth as indicated by the emergence of first leaves and continued root development started. Rhizoid's growth was reported in the embryo development of Ensete glaucum banana (Singh et al., 2020), which grew in 14 days of culture. In other monocot species, such as orchid Dendrophylax lindenii (Hoang et al., 2017) and Cyrtopodium saintlegerianum (Sousa et al., 2019), rhizoid structures are often found during zygotic embryo's early development into protocorms. Shoot growth from embryo cultures of $M$. acuminata var. tomentosa had a similarity in time with E. glaucum shoots development; the shoots manifested as the coleoptiles appeared at 14 days of culture and elongated at 16 DOC (Singh et al., 2020).

The hydropriming treatment of 1-day soaking also demonstrated that subsequent plantlet growth was also improved as indicated by more vigorous growth as indicated by shoots height and number of leaves, while the number of shoots and number of roots stays the same. During the immersion period, several physiological processes, including activation and synthesis of some enzymes, proteins, and amino acids, repair and increase in
ATP synthesis, and repair of plasma membranes in the soaked seeds will begin to develop, increasing the relative growth rate of the seedling produced (Oliveira et al., 2019). Several studies have shown that soaking seeds not only promotes germination but also increases seedling growth. Bakry (2008) reported that when the wild banana seed germination problem occurs due to old seeds with desiccated embryos, the seeds could be soaked for $48 \mathrm{~h}$ by immersion in sterile water after first surface sterilization to second surface sterilization before embryo extraction. Other study reported by Shah et al. (2012) said that seed priming increased early growth and seedling vigor of mung bean, characterized by an increase in seedling biomass. Bitter gourd seeds soaked in $45^{\circ} \mathrm{C}$ warm water for 5 min can also increase seedling growth and yields (Tania et al., 2019).

Plantlets that grew from germinated embryos from soaked and unsoaked seeds produced different coleoptile colors. The soaked seeds resulted in a greener seedling than the control unsoaked seeds did. Exogenous cytokinin (BA) which was added in the growth medium seems to play important role in the rate of seedling greening. According to Cortleven \& Schmülling (2015), the greening level is closely related to the chlorophyll content and abundance of chloroplasts as the result of cytokinin action in plant tissue. Cyto- 


\section{Jurnal Biodjati 6(1):11-22, May 2021 \\ JURNAL BI@DIATI}

http://journal.uinsgd.ac.id/index.php/biodjati

kinin not only accelerates chlorophyll biosynthesis by promoting ALA synthesis and enhancing POR activity but also regulates nuclear and plastid gene expression and alters protein abundance to carry out its role on chloroplast development and function. Green color differences expressed in control and treated seedlings were also reported in corn kernels soaked with water (hydropriming), $\mathrm{CaCl}_{2}$ and Moringa leaf extract (osmopriming), and salicylic acid (hormonal priming) (ur Rehman et al., 2015). The priming process or soaking of the pre-planted corn kernels produces seedlings with higher chlorophyll content than control seedlings so that the leaves are greener.

Based on the results, it can be concluded that seed soaking treatment as hydropriming increased the percentage of embryo germination and accelerated germination of M. acuminata var. tomentosa embryos. It continually affected embryo development into plantlets. Plantlets grown from seed-soaked sprouts had a higher vigor than sprouts from untreated seeds. However, soaking treatments carried an increased risk of contamination over the soaking duration. Thus, 1-day seed hydropriming is the best treatment for embryo rescue and regeneration of wild banana M. acuminata var. tomentosa.

\section{ACKNOWLEDGEMENTS}

The authors would like to thank Dian Mulyana, Omi, and Yuli for their technical assistance. The authors appreciate Witjaksono for critically reading the manuscript. This work was funded by Annual Research Budget 2020 (SP DIPA 079.01.1.664160/2020) under the Deputy of Life Sciences, Indonesian Institute of Sciences.

\section{REFERENCES}

Arun, K., Uma, S., Saraswathi, M. S., Backiyarani, S. \& Durai, P. (2013). Effects of Whole Seed Priming on the in vitro Germination of Hybrid Banana Embryos (Musa spp.). Seed Science and Technology, 41(3), 439-451.

Asif, M. J., Mak, C. \& Othman, R. Y. (2001). In vitro Zygotic Embryo Culture of Wild Musa acuminata ssp. malaccensis and Factors Affecting Germination and Seedling Growth. Plant Cell, Tissue and Organ Culture, 67(3), 267-270.

Bakry, F. (2008). Banana Protocol Zygotic Embryo Rescue in Bananas. Fruits, 63(2), 111-115.

Bohra, P., Waman, A. A. \& Jerard, B. A. (2020). Seed Germination and Storage Studies in Seed Fertile Musa indandamanensis and its Conservation. South African Journal of Botany, 128, 161-166.

Christelová, P., De Langhe, E., Hřibová, E., Č́žžková, J., Sardos, J., Hušáková, M., Van den houwe, I., Sutanto, A., Kepler, A. K., Swennen, R., Roux, N. \& Doležel, J. (2017). Molecular and Cytological Characterization of the Global Musa Germplasm Collection Provides Insights into the Treasure of Banana diversity. Biodiversity and Conservation, 26(4), 801-824.

Cortleven, A. \& Schmülling, T. (2015). Regulation of Chloroplast Development and Function by Cytokinin. Journal of Experimental Botany, 66(16), 4999-5013.

Dayarani, M., Dhanarajan, M. S., Arun, K., Uma, S. \& Narayani, P. (2014). Embryo Culture and Embryo Rescue Studies in Wild Musa spp. (Musa ornata). Journal of Applied Horticulture, 16(2), 126-130. 


\section{Jurnal Biodjati 6(1):11-22, May 2021 \\ JURNAL BIDDJATI}

http://journal.uinsgd.ac.id/index.php/biodjati

Diro, M. \& Van Staden, J. (2003). In vitro Regeneration of Ensete ventricosum from Zygotic Embryos of Stored Seeds. South African Journal of Botany, 69(3), 364-369.

Esmaeilpour, A. \& Van Damme, P. (2016). Evaluation of Seed Soaking Times on Germination Percentage, Germination Rate and Growth Characteristics of Pistachio Seedlings. Acta Horticulturae, 1109, 107-112.

Frank, A., Saldierna Guzmán, J. \& Shay, J. (2017). Transmission of Bacterial Endophytes. Microorganisms, 5(4), 70.

Hoang, N. H., Kane, M. E., Radcliffe, E. N., Zettler, L. W. \& Richardson, L. W. (2017). Comparative Seed Germination and Seedling Development of the Ghost Orchid, Dendrophylax lindenii (Orchidaceae), and Molecular Identification of its Mycorrhizal Fungus from South Florida. Annals of Botany, 119(3), 379-393.

Kallow, S., Longin, K., Sleziak, N. F., Janssens, S. B., Vandelook, F., Dickie, J., Swennen, R., Paofa, J., Carpentier, S. \& Panis, B. (2020). Challenges for ex situ Conservation of Wild Bananas: Seeds Collected in Papua New Guinea have Variable Levels of Desiccation Tolerance. Plants, 9(9), 1-21.

Mozumder, S. N. \& Hossain, M. M. (2013). Effect of Seed Treatment and Soaking Duration on Germination of Eryngium foetidum L. Seeds. International Journal of Horticulture, 3(10), 46-51.

Murashige, T. \& Skoog, F. (1962). A Revised Medium for Rapid Growth and Bio Assays with Tobacco Tissue Cultures. Physiologia Plantarum, 15, 473-497.

Oliveira, C. E. D. S., Steiner, F., Zuffo, A. M., Zoz, T., Alves, C. Z. \& De Aguiar, V. C. B. (2019). Seed Priming Improves the Germination and Growth Rate of Melon
Seedlings Under Saline Stress. Ciencia Rural, 49(7), 1-11.

Pawar, V. A. \& Laware, S. L. (2018). Seed Priming: A Critical Review. International Journal of Scientific Research in Biological Sciences, 5(5), 94-101.

Roostika, I., Sutanto, A., Edison, N. \& Dewi, N. (2019). Kultur Embrio Pisang Liar Musa acuminata ssp. sumatrana yang Langka. Jurnal Hortikultura, 28(1), 25-32.

Sabongari, S. \& Aliero, B. L. (2004). Effects of Soaking Duration on Germination and Seedling Growth of Tomato (Lycopersicum esculentum Mill). African Journal of Biotechnology, 3(1), 47-51.

Santos, A. S., Amorim, E. P., Ferreira, C. F. \& Pirovani, C. P. (2018). Water Stress in Musa spp.: A Systematic Review. PLoS ONE, 13(12), 1-17.

Shah, H., Jalwat, T., Arif, M. \& Miraj, G. (2012). Seed Priming Improves Early Seedling Growth and Nutrient Uptake in Mungbean. Journal of Plant Nutrition, 35(6), 805-816.

Siddique, A. \& Kumar, P. (2018). Physiological and Biochemical Basis of Presowing Soaking Seed Treatment - An Overview. Plant Archives, 18(2), 19331937.

Silva, M. D. S., Rodrigues, T. C., Aud, F. F., Dos Santos-Serejo, J. A. \& Amorim, E. P. (2019). Illustrated Guide to the Classification of Banana Seeds and Embryos. Revista Brasileira de Fruticultura, 41(2), 1-5.

Singh, S., Thangjam, R., Harish, G. D., Singh, H., Kumar, R., Meena, D. P. S. \& Agrawal, A. (2020). Conservation Protocols for Ensete glaucum, a Crop Wild Relative of Banana, using Plant Tissue Culture and Cryopreservation Tech- 


\section{Jurnal Biodjati 6(1):11-22, May 2021 \\ JURNAL BI@DIATI}

http://journal.uinsgd.ac.id/index.php/biodjati

niques on Seeds and Zygotic Embryos. Plant Cell, Tissue and Organ Culture, 144, 195-209.

Sousa, K. C. I., De Araújo, L. G., De Sousa Silva, C., De Carvalho, J. C. B., Sibov, S. T., De Almeida Gonçalves, L., Pereira, M. C., Gonçalves, F. J. \& Da Corsi De Filippi, M. C. (2019). Seed Germination and Development of Orchid Seedlings (Cyrtopodium saintlegerianum) with Fungi. Rodriguesia, 70, 1-11.

Sulistyaningsih, L. D. (2013). Pisang-pisangan (Musaceae) di Gunung Watuwila dan Daerah Sekitarnya. Floribunda, 4(5), 121-125.

Tania, S. S., Hossain, M. M. \& Hossain, M. A. (2019). Effects of Hydropriming on Seed Germination, Seedling Growth and Yield of Bitter Gourd. Journal of the Bangladesh Agricultural University, 17(3), 281-287.

Tenkouano, A., Vuylsteke, D., Okoro, J., Makumbi, D., Swennen, R. \& Ortiz, R. (2003). Diploid Banana Hybrids TMB2 $\times 5105-1$ and TMB2x9128-3 with Good Combining Ability, Resistance to Black Sigatoka and Nematodes. HortScience, 38(3), 468-472.

Uma, S., Lakshmi, S., Saraswathi, M. S., Akbar, A. \& Mustaffa, M. M. (2011). Embryo Rescue and Plant Regeneration in Banana (Musa spp.). Plant Cell, Tissue and Organ Culture, 105(1), 105-111.

Uma, S., Lakshmi, S., Saraswathi, M. S., Akbar, A. \& Mustaffa, M. M. (2012). Plant Regeneration through Somatic Embryogenesis from Immature and Mature Zygotic Embryos of Musa acuminata ssp. burmannica. In Vitro Cellular and Developmental Biology - Plant, 48(5), 539-545. ur Rehman, H., Iqbal, H., Basra, S. M. A., Afzal, I., Farooq, M., Wakeel, A. \& Wang, N. (2015). Seed Priming Improves Early Seedling Vigor, Growth and Productivity of Spring Maize. Journal of Integrative Agriculture, 14(9), 1745-1754.

Wilson, V. \& Tenkouano, A. (2019). Effects of Storage and Priming on Seed Emergence in Soil and Embryo Culture of Musa acuminata Calcutta 4. Asian Plant Research Journal, 2(1), 1-9.

Wu, W., Yang, Y. L., He, W. M., Rouard, M., Li, W. M., Xu, M., Roux, N. \& Ge, X. J. (2016). Whole Genome Sequencing of a Banana Wild Relative Musa itinerans Provides Insights into Lineage-Specific Diversification of the Musa Genus. Scientific Reports, 6, 1-11.

Zhang, C., Wu, J., Fu, D., Wang, L., Chen, J., Cai, C. \& Ou, L. (2015). Soaking, Temperature, and Seed Placement Affect Seed Germination and Seedling Emergence of Litchi chinensis. HortScience, 50(4), 628-632.

Zhang, L., Cenci, A., Rouard, M., Zhang, D., Wang, Y., Tang, W. \& Zheng, S. J. (2019). Transcriptomic Analysis of Resistant and Susceptible Banana Corms in Response to Infection by Fusarium oxysporum f. sp. cubense Tropical Race 4. Scientific Reports, 9(1), 1-14. 